DOI: 10.17805/trudy.2015.2.6

\title{
ГОДИЧНАЯ СЕССИЯ РУССКОЙ СЕКЦИИ МЕЖДУНАРОДНОЙ АКАДЕМИИ НАУК
}

\author{
С. В. Луков \\ (Московский гуманитарный университет)
}

Аннотация: В статье представлен обзор работы Годичной сессии Русской секции Международной академии наук, которая состоялась 16 января 2015 г. в Государственном геологическом музее им. В. И. Вернадского РАН.

Ключевые слова: Международная академия наук, Русская секция Международной академии наук, обзор, годичная сессия.

\section{THE ANNUAL MEETING OF THE RUSSIAN SECTION, INTERNATIONAL ACADEMY OF SCIENCES}

\author{
S. V. Lukov \\ (Moscow University for the Humanities)
}

Abstract: The article presents a review of the yearly work of the Russian section, International Academy of Sciences, as it was discussed at the annual meeting which took place on January 16, 2015 at the V.I. Vernadsky State Geology Museum, Russian Academy of Sciences.

Keywords: International Academy of Sciences, Russian section, review, annual meeting.

16 января 2015 г. в Государственном геологическом музее им. В.И.Вернадского РАН состоялась годичная сессия Русской секции Международной академии наук (IAS, штаб-квартира в г. Инсбрук, Австрия).

Участников сессии приветствовал Президент Международной академии наук, академик Вальтер Кофлер (Австрия). Участники утвердили Отчет о деятельности РС МАН в 2013-2014 гг., избрали руководящие органы этого общественного объединения ученых - представителей естественнонаучных, гуманитарных, медицинских, технических наук. В отчетном докладе, который сделал вице-президент РС МАН академик О. С. Глазачев, был отражен значительный вклад Московского гуманитарного университета как базовой организации отделения гуманитарных наук РС МАН 
в реализацию научных программ и проектов МАН, проведение крупных международных научных конференций, издание монографий, сборников научных статей под грифом Академии, научных журналов.

С научным докладом, традиционно представляемым на годичной сессии одним из ведущих ученых - академиком МАН, выступил проректор по научной и издательской работе - директор Института фундаментальных и прикладных исследований Московского гуманитарного университета академик Вал. А. Луков. Его доклад «Теория функциональных систем П. К. Анохина - К. В. Судакова и тезаурусный подход» был посвящен памяти ушедших из жизни выдающихся российских ученых - академиков МАН К. В. Судакова и Вл. А. Лукова. Труды К. В. Судакова в области физиологии и Вл. А. Лукова в области культурологии были показаны как методологически близкие, прокладывающие путь к утверждению междисциплинарных и трансдисциплинарных исследований. Доклад был выслушан академиками с большим интересом и получил высокие оценки в ряде выступлений.

На сессии Президент МАН В. Кофлер вручил новым академикам и членам-корреспондентам МАН дипломы, подтверждающие их избрание. Среди получивших дипломы членов-корреспондентов МАН - заместители директора Центра теории и истории культуры ИФПИ МосГУ Б. Н. Гайдин и В. С. Макаров, получившие международное признание рядом своих исследований, проведенных в последнее время. Бронзовым знаком имени И. П. Павлова и грантом-стипендией, учрежденной МАН для поддержки молодых ученых России, удостоен также выходец из научной школы МосГУ, ныне доцент Российского экономического университета им. Г. В. Плеханова Д. А. Тихомиров.

В ходе сессии состоялись встречи и переговоры о сотрудничестве с Президентом МАН В. Кофлером, членами президиума РС МАН, академиками МАН, в которых участвовали представляющие в Международной академии наук Московский гуманитарный университет академики МАН Н. В. Захаров, А. В. Костина, Вал. А. Луков и др. Среди прочих обсуждена идея возрождения Института человека в тесном сотрудничестве научных организаций, ведущих междисциплинарные исследования в этой области, - Института философии РАН, Института фундаментальных и прикладных исследований Московского гуманитарного университета, ряда других образовательных и научных организаций, а также с привлечением большого потенциала Русской секции Международной академии наук.

Луков Сергей Валерьевич - кандидат социологических наук, заместитель директора Центра социологии молодежи Института фундаментальных и прикладных исследований Московского гуманитарного уни- 
верситета. Адрес: 111395, Россия, г. Москва, ул. Юности, д. 5, корп. 6. Тел.: +7 (499) 374-75-95. Эл. адрес: sv-lukov@rambler.ru

Lukov Sergey Valerievich, Candidate of Sociology, Master of Social Work (Germany), Deputy Director, Center for Youth Sociology, Institute of Fundamental and Applied Studies, Moscow University for the Humanities. Postal address: 5 Yunosti St., 111395 Moscow, Russian Federation. Tel.: +7 (499) 374-75-95.E-mail: sv-lukov@rambler.ru 